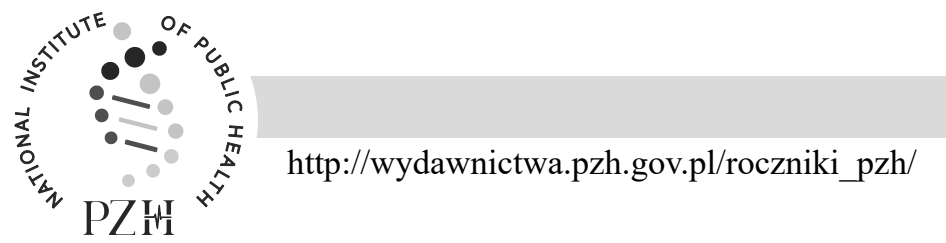

\title{
FREQUENCY OF CONSUMING SELECTED PRODUCT GROUPS AMONG POLISH AND SPANISH PHYSICAL EDUCATION STUDENTS
}

\author{
Maria Gacekl, Grażyna Kosiba², Agnieszka Wojtowicz
}

${ }^{1}$ Department of Sports Medicine and Human Nutrition, University of Physical Education in Kraków, Poland ${ }^{2}$ Department of Theory and Methodology of Physical Education, University of Physical Education in Kraków, Poland

${ }^{3}$ Department of Psychology, University of Physical Education in Kraków, Poland

\begin{abstract}
Background. Nutritional behaviours are determined by numerous individual and environmental factors.

Objective. The aim of the study was to analyse the frequency of consuming selected food product groups (with potentially beneficial and potentially detrimental effects on health) among physical education students depending on gender and home country.

Materials and methods. The study was conducted among 219 Polish and 280 Spanish physical education students, using a standardised questionnaire for obtaining information on views and eating habits for people aged 16-65 (Kom-PAN). In the statistical analysis, the Mann-Whitney $\mathrm{U}$ test and t-test with independent estimation of variance were incorporated, the significance level at $\alpha=0.05$.

Results. Among Polish and Spanish students, significant differences in the frequency of consuming certain product groups depending on home country were noted, with Polish students significantly more frequently consuming recommended products (fruit, vegetables, whole-grains, milk, fromage frais, and poultry), but also those non-recommended (purified cereals, cheeses with high fat content, butter, fried foods, sweets and alcoholic beverages). Spanish students significantly more often consumed recommended meals including legume seeds and sea fish, but also non-recommended products (red meat, fast food, sweets and energy drinks). Moreover, significant differences in the frequency of consuming selected product groups depending on sex were observed, with an indication of the tendency for less rational food choices among male students than female students, especially regarding the consumption of: high-milled cereal products, processed and red meat, fatty cheeses, fried foods, lard, sweets and energy drinks. On the other hand, women consumed sweets significantly more often than men, and less often legume seeds and fish.

Conclusions. A limited prevalence of rational dietary choices among Polish and Spanish physical education students and their diversity depending on gender and home country have been demonstrated.
\end{abstract}

Key words: frequency of food consumption, conditioning of food choices, physical education students

\section{STRESZCZENIE}

Wprowadzenie. Zachowania żywieniowe są determinowane licznymi czynnikami osobniczymi i środowiskowymi.

Cel. Celem badań była analiza częstości konsumpcji wybranych grup produktów (o potencjalnie korzystnym i potencjalnie niekorzystnym wpływie na zdrowie) wśród studentów wychowania fizycznego w zależności od płci oraz kraju pochodzenia.

Material i metody. Badania przeprowadzono wśród 219 polskich i 280 hiszpańskich studentów wychowania fizycznego, z zastosowaniem standaryzowanego kwestionariusza do poglądów i zwyczajów żywieniowych dla osób w wieku od 16 do 65 lat (Kom-PAN). W analizie statystycznej zastosowano test U Manna-Whitneya i test t z niezależną estymacją wariancji, na poziomie istotności $\alpha=0,05$.

Wyniki. Wśród polskich i hiszpańskich studentów wykazano istotne zróżnicowanie częstości konsumpcji niektórych grup produktów w zależności od kraju, przy czym polscy studenci istotnie częściej spożywali produkty rekomendowane (owoce, warzywa, zbożowe pełnoziarniste, mleko, sery twarogowe, mięso drobiowe), ale także niezalecane (zbożowe oczyszczone, tłuste sery, masło, potrawy smażone, słodycze, napoje alkoholowe). Hiszpańscy studenci istotnie częściej spożywali zalecane potrawy z nasion strączkowych i ryb morskich, ale także niezalecane (mięso czerwone, fast food, napoje słodkie i energetyzujące). Wykazano ponadto istotne zróżnicowanie częstości konsumpcji niektórych grup produktów w zależności od płci, ze wskazaniem na tendencję do mniej racjonalnych wyborów żywieniowych studentów niż studentek, szczególnie w zakresie konsumpcji: produktów zbożowych z wysokiego przemiału, przetworów mięsnych,

Corresponding author: Maria Gacek, Department of Sports Medicine and Human Nutrition, University of Physical Education in Kraków, Al. Jana Pawła II 79, 31-571 Kraków, Poland, Phone: +48 1268311 45, e-mail: maria.gacek@awf.krakow.pl

(C) Copyright by the National Institute of Public Health - National Institute of Hygiene 
mięsa czerwonego, tłustych serów, potraw smażonych, smalcu oraz napojów słodkich i energetyzujących. Kobiety natomiast istotnie częściej niż mężczyźni spożywały słodycze, a rzadziej nasiona strączkowe i ryby.

Wnioski. Wykazano ograniczone rozpowszechnienie racjonalnych wyborów żywieniowych wśród polskich i hiszpańskich studentów wychowania fizycznego oraz ich zróżnicowanie w zależności od płci i kraju pochodzenia.

Słowa kluczowe: częstość spożycia żywności, uwarunkowania wyborów żywieniowych, studenci wychowania fizycznego

\section{INTRODUCTION}

The correct nutritional model, taking age, gender, level of physical activity and health into account, is one of the important factors contributing to maintaining health potential and prevention of chronic diseases, including obesity, type 2 diabetes, cardiovascular diseases and some cancers. A rational diet should be diverse and balanced, including products with high nutritional value (fruit and vegetables, whole-grains, low-fat dairy products, fish and vegetable oils as well as nuts), with restrictions on animal fats, red and processed meat products, purified cereal products as well as confectionery and fast food products [20]. The rational nutrition model, as an important health determinant, in many countries, including Poland and Spain, has been included in the canon of basic aspects of a healthy lifestyle (Polish Pyramid of Physical Activity and Healthy Nutrition from 2016 and the Spanish Strategy for Nutrition, Physical Activity and Prevention of Obesity from 2008) [16].

A group with special nutritional needs includes people characterised by increased physical activity - i.e. athletes and physical education students who demonstrate a significantly higher level of physical activity than students of other university faculties $[19,21,40]$. Interest in this population group is also associated with the role of physical education students (future teachers) in the implementation of school health education [22]. In various studies, it has been confirmed that the intensification of teachers' pro-health attitudes increases the effectiveness of promoting a healthy lifestyle, including the implementation of a rational diet [3]. Nutritional behaviours are determined by numerous individual and environmental factors, including cultural ones [33]. Within the context of increased physical activity among P.E. students and their preparation for the future role of health educators of children and adolescents, assuming the geographical and cultural diversity of eating behaviours, research has been undertaken regarding selected determinants of the nutritional choices among physical education students with a profile focused on physical culture and health.

The aim of the study was to analyse the frequency of consuming selected product groups (with potentially beneficial and detrimental effects on health) among physical education students depending on gender and home country.

\section{MATERIALS AND METHODS}

Research was conducted between the years 20172019 among $4992^{\text {nd }}$ - and $3^{\text {rd- }}$ year physical education students (B. A. studies), aged 18 to 35 (21.65 2.42 ). The study included 219 Polish students (University of Physical Education in Kraków, $\mathrm{n}=135$; and University of Physical Education in Wrocław, $n=84$ ) and 280 Spanish students (University of Murcia, Faculty of Sports Sciences, $n=127$; and University in Granada, Faculty of Sports Sciences, $\mathrm{n}=153$ ).

In the study, a standardised questionnaire was used to evaluate views and habits related to nutrition. This survey is dedicated to subjects aged 16 to 65 (KomPAN), and was developed by the Human Nutrition Science Committee of the Polish Academy of Sciences, in the part concerning the frequency of consuming selected groups of food products. The frequency of consuming products was assessed on an ordinal scale: never (1), 1-3 times a month (2), once a week (3), several times a week (4), once a day (5), several times a day (6) [13]. The general index of rational and incorrect nutrition choices was calculated as the total value of the average frequency of consuming individual products from a particular category. The group of products with potentially beneficial effects on health $(n=10)$ includes: wholemeal bread; buckwheat, oatmeal, whole-grain pasta and other coarse grains; milk; beverages from fermented dairy products; fromage frais; dishes from the so-called white meat; fish; legume seed dishes; fruits and vegetables. The group of products with potentially adverse effects on health $(n=14)$ are: white bread; white rice, plain pasta or fine-grained groats; fast food; fried foods; butter; lard; cheese; cold-cuts, sausages or hotdogs; red meat dishes; sweets; canned meat; sweetened carbonated or non-carbonated beverages; energy drinks and alcoholic beverages [13].

The IBM SPSS 21 program and Newsom's macro J.T. were used for statistical calculations. Basic statistics of the studied variables were calculated (mean, standard deviation, median, upper and lower quartiles). Differentiation in the frequency of product consumption (with potentially beneficial and potentially adverse effects on health) depending on gender and country of origin of students was assessed using the Mann-Whitney $\mathrm{U}$ test while the $t$-test with independent estimation of variance was applied to 
compare the general index of rational and incorrect dietary choices. The adopted level of significance was $\alpha=0.05$.

\section{RESULTS}

Among the products with potentially beneficial effects on health, the examined group of physical education students most often, usually several times a week $(\mathrm{Me}=4)$, consumed: fruit and vegetables, milk, fermented dairy products and poultry, while among products with potentially detrimental influence on health, the following were noted: white bread, other high-milled cereal products, cold-cuts, sausages and hotdogs (Table 1).

Statistical analysis of the results depending on home country showed that among products with a potentially beneficial effect on health, Polish students, significantly more often, consumed: fruit and vegetables, wholemeal bread $(p<0.001)$, other low-milled cereal products $(p=0.001)$, milk $(p<0.05)$, fromage frais $(p<0.001)$ and poultry meat $(p<0.001)$, while the frequency of consuming legume seeds and fish was significantly higher among the Spanish students $(p<0.001)$ (Table 2$)$.

Among products with potentially adverse effects on health, Polish physical education students consumed the following significantly more often: white bread $(p<0.01)$, other high-milled cereal products $(p<0.05)$, hard, blue and processed soft cheeses $(p<0.001)$, fried foods $(p<0.001)$, butter $(p<0.001)$, sweets and confectionery $(p<0.001)$ as well as alcoholic beverages ( $p=0.001$ ), while Spanish students included the following products in the diets more frequently: red meat, fast food $(p<0.001)$, sweetened carbonated beverages and energy drinks $(p<0.05)$ (Table 3$)$.

Statistical analysis of the results depending on sex showed that among the products with potentially beneficial effects on health, the surveyed men, significantly more often than women, consumed: legume seeds and fish $(p<0.05)$, and among the products with potentially adverse effects on health: white bread $(p<0.05)$, other high-milled cereal products $(p<0.01)$, cold-cuts, sausages and hotdogs $(p<0.01)$, red meat

Table 1. Frequency of consuming potentially beneficial and detrimental products among Polish and Spanish physical education students $(\mathrm{n}=499)$ (descriptive statistics)

\begin{tabular}{|c|c|c|c|c|c|c|}
\hline \multirow{2}{*}{\multicolumn{2}{|c|}{ Categories of food products $\mathrm{M}$}} & \multicolumn{5}{|c|}{ Poland and Spain } \\
\hline & & \multirow{2}{*}{$\begin{array}{c}\mathrm{M} \\
4.02\end{array}$} & \multirow{2}{*}{$\begin{array}{l}\mathrm{Me} \\
4.00\end{array}$} & \multirow{2}{*}{$\begin{array}{l}\text { Q25 } \\
3.00\end{array}$} & \multirow{2}{*}{$\begin{array}{l}\text { Q75 } \\
5.00\end{array}$} & \multirow{2}{*}{$\begin{array}{l}\text { SD } \\
1.49\end{array}$} \\
\hline \multirow{10}{*}{ influence on health } & Fruit & & & & & \\
\hline & Vegetables & 4.02 & 4.00 & 3.00 & 5.00 & 1.44 \\
\hline & Wholemeal bread & 3.20 & 3.00 & 2.00 & 4.00 & 1.41 \\
\hline & Coarse-grained barley, oatmeal, whole-grain pasta & 3.25 & 3.00 & 2.00 & 4.00 & 1.19 \\
\hline & Legume seeds & 3.06 & 3.00 & 2.00 & 4.00 & 1.16 \\
\hline & Milk & 3.55 & 4.00 & 2.00 & 5.00 & 1.66 \\
\hline & Fermented dairy products & 3.39 & 4.00 & 2.00 & 4.00 & 1.34 \\
\hline & Fromage frais & 2.89 & 3.00 & 2.00 & 4.00 & 1.15 \\
\hline & Poultry & 3.68 & 4.00 & 3.00 & 4.00 & 1.09 \\
\hline & Fish & 3.00 & 3.00 & 2.00 & 4.00 & 1.02 \\
\hline \multirow{14}{*}{$\begin{array}{l}\text { Potentially detrimental } \\
\text { influence on health }\end{array}$} & White bread & 3.32 & 4.00 & 2.00 & 4.00 & 1.54 \\
\hline & White rice, finely-ground barley & 3.60 & 4.00 & 3.00 & 4.00 & 1.08 \\
\hline & Hard, blue, soft cheeses, processed cheese spreads & 3.00 & 3.00 & 2.00 & 4.00 & 1.16 \\
\hline & Cold-cuts, sausages, hotdogs & 3.54 & 4.00 & 3.00 & 4.00 & 1.21 \\
\hline & Red meat & 3.12 & 3.00 & 2.00 & 4.00 & 1.13 \\
\hline & Canned meat & 2.26 & 2.00 & 2.00 & 3.00 & 1.04 \\
\hline & Fried meals (farinaceous and meat) & 3.27 & 3.00 & 2.00 & 4.00 & 1.11 \\
\hline & Butter & 2.90 & 2.00 & 2.00 & 4.00 & 1.38 \\
\hline & Lard & 1.94 & 2.00 & 1.00 & 2.00 & 1.05 \\
\hline & Fast food & 2.49 & 2.00 & 2.00 & 3.00 & 0.93 \\
\hline & Sweets, confectionary & 3.09 & 3.00 & 2.00 & 4.00 & 1.22 \\
\hline & Sweetened carbonated and non-carbonated beverages & 2.57 & 2.00 & 2.00 & 3.00 & 1.15 \\
\hline & Energy drinks & 2.33 & 2.00 & 2.00 & 3.00 & 1.14 \\
\hline & Alcoholic beverages & 2.61 & 2.00 & 2.00 & 3.00 & 1.03 \\
\hline
\end{tabular}

M- arithmetic mean; Me- median; Q25- lower quartile; Q75- upper quartile; SD- standard deviation 
Table 2. Frequency of consuming products with potentially beneficial influence on health among Polish ( $\mathrm{n}=219)$ and Spanish ( $\mathrm{n}=280$ ) physical education students depending on home country (descriptive statistics and Mann-Whitney U test)

\begin{tabular}{|c|c|c|c|c|c|c|c|c|c|c|c|}
\hline \multirow{2}{*}{ Food products } & \multicolumn{5}{|c|}{ Spain } & \multicolumn{5}{|c|}{ Poland } & \multirow{2}{*}{$p$} \\
\hline & $\mathrm{M}$ & $\mathrm{Me}$ & Q25 & Q75 & $\mathrm{SD}$ & $\mathrm{M}$ & $\mathrm{Me}$ & Q25 & Q75 & $\mathrm{SD}$ & \\
\hline Fruit & 3.71 & 4.00 & 2.00 & 5.00 & 1.69 & 4.41 & 4.00 & 4.00 & 5.00 & 1.05 & $<0.001$ \\
\hline Vegetables & 3.58 & 4.00 & 2.00 & 5.00 & 1.53 & 4.58 & 4.00 & 4.00 & 5.00 & 1.08 & $<0.001$ \\
\hline Wholemeal bread & 2.95 & 2.00 & 2.00 & 4.00 & 1.43 & 3.52 & 4.00 & 2.00 & 4.00 & 1.33 & $<0.001$ \\
\hline $\begin{array}{l}\text { Coarse-grained barley, oatmeal, } \\
\text { whole-grain pasta }\end{array}$ & 3.10 & 3.00 & 2.00 & 4.00 & 1.24 & 3.44 & 4.00 & 3.00 & 4.00 & 1.10 & 0.001 \\
\hline Legume seeds & 3.33 & 3.00 & 3.00 & 4.00 & 1.20 & 2.70 & 3.00 & 2.00 & 3.00 & 1.00 & $<0.001$ \\
\hline Milk & 3.34 & 4.00 & 1.00 & 5.00 & 1.89 & 3.81 & 4.00 & 3.00 & 5.00 & 1.25 & 0.021 \\
\hline Fermented dairy products & 3.34 & 4.00 & 2.00 & 4.00 & 1.47 & 3.45 & 4.00 & 3.00 & 4.00 & 1.15 & 0.438 \\
\hline Fromage frais & 2.68 & 2.00 & 2.00 & 3.50 & 1.11 & 3.16 & 3.00 & 2.00 & 4.00 & 1.15 & $<0.001$ \\
\hline Poultry & 3.50 & 4.00 & 3.00 & 4.00 & 1.23 & 3.91 & 4.00 & 4.00 & 4.00 & 0.82 & $<0.001$ \\
\hline Fish & 3.17 & 3.00 & 2.50 & 4.00 & 1.08 & 2.79 & 3.00 & 2.00 & 3.00 & 0.88 & $<0.001$ \\
\hline
\end{tabular}

M - arithmetic mean; Me - median; Q25 - lower quartile; Q75 - upper quartile; SD - standard deviation; $p$ - significance

Table 3. Frequency of consuming products with potentially detrimental influence on health among Polish ( $\mathrm{n}=219)$ and Spanish ( $\mathrm{n}=280)$ physical education students depending on home country (descriptive statistics and Mann-Whitney U test)

\begin{tabular}{|l|c|c|c|c|c|c|c|c|c|c|c|}
\hline \multirow{2}{*}{ Food products } & \multicolumn{4}{|c}{ Spain } & \multicolumn{5}{c|}{ Poland } & \multicolumn{1}{c|}{$p$} \\
\cline { 2 - 11 } & $\mathrm{M}$ & $\mathrm{Me}$ & $\mathrm{Q} 25$ & $\mathrm{Q} 75$ & $\mathrm{SD}$ & $\mathrm{M}$ & $\mathrm{Me}$ & $\mathrm{Q} 25$ & $\mathrm{Q} 75$ & SD & \\
\hline White bread & 3.14 & 3.00 & 2.00 & 4.00 & 1.61 & 3.54 & 4.00 & 2.00 & 4.00 & 1.41 & 0.004 \\
\hline White rice, finely-ground barley & 3.51 & 4.00 & 3.00 & 4.00 & 1.11 & 3.72 & 4.00 & 3.00 & 4.00 & 1.04 & 0.026 \\
\hline Hard and blue, soft cheeses & 2.74 & 2.00 & 2.00 & 4.00 & 1.14 & 3.33 & 4.00 & 2.00 & 4.00 & 1.11 & $<0.001$ \\
\hline Cold-cuts, sausages, hotdogs & 3.45 & 4.00 & 3.00 & 4.00 & 1.27 & 3.65 & 4.00 & 3.00 & 4.00 & 1.12 & 0.130 \\
\hline Red meat & 3.28 & 3.00 & 2.00 & 4.00 & 1.17 & 2.90 & 3.00 & 2.00 & 4.00 & 1.05 & $<0.001$ \\
\hline Canned meat & 2.60 & 2.0 & 2.0 & 3.0 & 1.01 & 1.83 & 2.0 & 1.0 & 2.0 & 0.91 & $<0.001$ \\
\hline $\begin{array}{l}\text { Fried meals (farinaceous and } \\
\text { meat) }\end{array}$ & 2.95 & 3.00 & 2.00 & 4.00 & 1.02 & 3.68 & 4.00 & 3.00 & 4.00 & 1.10 & $<0.001$ \\
\hline Butter & 2.54 & 2.00 & 2.00 & 3.00 & 1.05 & 3.36 & 4.00 & 2.00 & 5.00 & 1.60 & $<0.001$ \\
\hline Lard & 2.25 & 2.00 & 2.00 & 2.00 & 1.03 & 1.53 & 1.00 & 1.00 & 2.00 & 0.93 & $<0.001$ \\
\hline Fast food & 2.64 & 2.00 & 2.00 & 3.00 & 0.98 & 2.31 & 2.00 & 2.00 & 3.00 & 0.82 & $<0.001$ \\
\hline Sweets, confectionary & 2.75 & 3.00 & 2.00 & 4.00 & 1.11 & 3.53 & 4.00 & 3.00 & 4.00 & 1.20 & $<0.001$ \\
\hline $\begin{array}{l}\text { Sweetened carbonated and non- } \\
\text { carbonated beverages }\end{array}$ & 2.65 & 2.00 & 2.00 & 3.00 & 1.07 & 2.47 & 2.00 & 1.00 & 3.00 & 1.25 & 0.036 \\
\hline Energy drinks & 2.41 & 2.00 & 2.00 & 3.00 & 1.08 & 2.22 & 2.00 & 1.00 & 3.00 & 1.20 & 0.012 \\
\hline Alcoholic beverages & 2.50 & 2.00 & 2.00 & 3.00 & 1.02 & 2.75 & 3.00 & 2.00 & 3.00 & 1.03 & 0.001 \\
\hline
\end{tabular}

M - arithmetic mean; Me - median; Q25 - lower quartile; Q75 - upper quartile; SD - standard deviation; $p$ - significance

( $p<0.001)$, canned meat $(p<0.01)$, hard, blue and processed soft cheeses $(p<0.001)$, fried foods $(p<0.05)$, lard $(p<0.01)$, and sweetened carbonated beverages as well as energy drinks $(p<0.001)$, while women more often reached for sweets and confectionery $(p=0.001)$ (Tables 4 and 5).

Statistical analysis showed that Polish students were characterised by a significantly higher level of rational food choices $(p<0.001)$, but at the same time, they consumed products with potentially adverse effects on health more often than students from Spain $(p<0.05)$ (Table 6).

\section{DISCUSSION}

The discussed research showed a limited prevalence of rational food choices among Polish and Spanish physical education students and their differentiation depending on gender and home country.

The indicated nutritional mistakes of all the surveyed students were particularly associated with the low frequency of consuming selected the products recommended for one's daily diet (fruit and vegetables, whole-grain cereals, fermented dairy products), as well as the relatively frequent consumption of meat 
Table 4. Frequency of consuming products with potentially beneficial influence on health among female ( $\mathrm{n}=189)$ and male $(\mathrm{n}=309)$ physical education students from Poland and Spain (descriptive statistics and Mann-Whitney U test)

\begin{tabular}{|c|c|c|c|c|c|c|c|c|c|c|c|}
\hline \multirow{2}{*}{ Food products } & \multicolumn{5}{|c|}{ Men } & \multicolumn{5}{|c|}{ Women } & \multirow{2}{*}{$p$} \\
\hline & $\mathrm{M}$ & $\mathrm{Me}$ & Q25 & Q75 & $\mathrm{SD}$ & $\mathrm{M}$ & $\mathrm{Me}$ & Q25 & Q75 & $\mathrm{SD}$ & \\
\hline Fruit & 3.99 & 4.00 & 3.00 & 5.00 & 1.47 & 4.07 & 4.00 & 3.00 & 5.00 & 1.51 & 0.398 \\
\hline Vegetables & 3.99 & 4.00 & 3.00 & 5.00 & 1.37 & 4.07 & 4.00 & 4.00 & 5.00 & 1.53 & 0.243 \\
\hline Wholemeal bread & 3.11 & 3.00 & 2.00 & 4.00 & 1.37 & 3.35 & 4.00 & 2.00 & 4.00 & 1.47 & 0.090 \\
\hline $\begin{array}{l}\text { Coarse-grained barley, oatmeal, } \\
\text { whole-grain pasta }\end{array}$ & 3.22 & 3.00 & 2.00 & 4.00 & 1.20 & 3.31 & 3.00 & 2.00 & 4.00 & 1.17 & 0.432 \\
\hline Legume seeds & 3.14 & 3.00 & 2.00 & 4.00 & 1.15 & 2.93 & 3.00 & 2.00 & 4.00 & 1.16 & 0.048 \\
\hline Milk & 3.55 & 4.00 & 2.00 & 5.00 & 1.65 & 3.54 & 4.00 & 2.00 & 5.00 & 1.67 & 0.973 \\
\hline Fermented dairy products & 3.34 & 4.00 & 2.00 & 4.00 & 1.33 & 3.47 & 4.00 & 3.00 & 4.00 & 1.35 & 0.260 \\
\hline Fromage frais & 2.86 & 3.00 & 2.00 & 4.00 & 1.14 & 2.94 & 3.00 & 2.00 & 4.00 & 1.16 & 0.441 \\
\hline Poultry & 3.73 & 4.00 & 3.00 & 4.00 & 1.12 & 3.59 & 4.00 & 3.00 & 4.00 & 1.04 & 0.139 \\
\hline Fish & 3.08 & 3.00 & 2.00 & 4.00 & 1.01 & 2.88 & 3.00 & 2.00 & 4.00 & 1.02 & 0.020 \\
\hline
\end{tabular}

M- arithmetic mean; Me- median; Q25- lower quartile; Q75- upper quartile; SD- standard deviation; $p$ - significance

Table 5. Frequency of consuming products with potentially detrimental influence on health among female (n=189) and male ( $\mathrm{n}=309)$ physical education students from Poland and Spain (descriptive statistics and Mann-Whitney U test)

\begin{tabular}{|c|c|c|c|c|c|c|c|c|c|c|c|}
\hline \multirow{2}{*}{ Food products } & \multicolumn{5}{|c|}{ Men } & \multicolumn{5}{|c|}{ Women } & \multirow{2}{*}{$p$} \\
\hline & M & $\mathrm{Me}$ & Q25 & Q75 & $\mathrm{SD}$ & M & $\mathrm{Me}$ & Q25 & Q75 & $\mathrm{SD}$ & \\
\hline White bread & 3.42 & 4.00 & 2.00 & 5.00 & 1.56 & 3.15 & 3.00 & 2.00 & 4.00 & 1.50 & 0.037 \\
\hline White rice, finely-ground barley & 3.72 & 4.00 & 3.00 & 4.00 & 1.07 & 3.41 & 4.00 & 3.00 & 4.00 & 1.09 & 0.003 \\
\hline Hard and blue, soft cheeses & 3.00 & 3.00 & 2.00 & 4.00 & 1.17 & 2.99 & 3.00 & 2.00 & 4.00 & 1.14 & 0.967 \\
\hline Cold-cuts, sausages, hotdogs & 3.66 & 4.00 & 3.00 & 4.00 & 1.22 & 3.34 & 4.00 & 3.00 & 4.00 & 1.16 & 0.002 \\
\hline Red meat & 3.35 & 3.00 & 3.00 & 4.00 & 1.09 & 2.73 & 3.00 & 2.00 & 4.00 & 1.10 & $<0.001$ \\
\hline Canned meat & 2.34 & 2.0 & 2.0 & 3.0 & 1.03 & 2.14 & 2.0 & 1.0 & 3.0 & 1.04 & 0.017 \\
\hline $\begin{array}{l}\text { Fried meals (farinaceous and } \\
\text { meat) }\end{array}$ & 3.36 & 4.00 & 2.00 & 4.00 & 1.11 & 3.13 & 3.00 & 2.00 & 4.00 & 1.11 & 0.041 \\
\hline Butter & 2.85 & 2.00 & 2.00 & 4.00 & 1.29 & 2.98 & 3.00 & 2.00 & 4.00 & 1.51 & 0.548 \\
\hline Lard & 2.00 & 2.00 & 1.00 & 2.00 & 1.02 & 1.81 & 2.00 & 1.00 & 2.00 & 1.05 & 0.005 \\
\hline Fast food & 2.54 & 2.00 & 2.00 & 3.00 & 0.92 & 2.41 & 2.00 & 2.00 & 3.00 & 0.89 & 0.069 \\
\hline Sweets, confectionary & 2.95 & 3.00 & 2.00 & 4.00 & 1.16 & 3.33 & 3.00 & 2.00 & 4.00 & 1.27 & 0.001 \\
\hline $\begin{array}{l}\text { Sweetened carbonated and non- } \\
\text { carbonated beverages }\end{array}$ & 2.77 & 3.00 & 2.00 & 4.00 & 1.16 & 2.24 & 2.00 & 1.00 & 3.00 & 1.06 & $<0.001$ \\
\hline Energy drinks & 2.46 & 2.00 & 2.00 & 3.00 & 1.11 & 2.11 & 2.00 & 1.00 & 2.00 & 1.15 & $<0.001$ \\
\hline Alcoholic beverages & 2.64 & 2.00 & 2.00 & 3.00 & 1.08 & 2.55 & 2.00 & 2.00 & 3.00 & 0.94 & 0.652 \\
\hline
\end{tabular}

M - arithmetic mean; Me - median; Q25- lower quartile; Q75 - upper quartile; SD - standard deviation; $p$ - significance

Table 6. Comparison of the level of rational and incorrect nutritional choices among physical education students from Poland $(\mathrm{n}=219)$ and Spain $(\mathrm{n}=280)(t$-test $)$

\begin{tabular}{|c|c|c|c|c|c|c|c|c|c|}
\hline $\begin{array}{c}\text { Nutritional } \\
\text { choices }\end{array}$ & $\begin{array}{c}\mathrm{M} \\
\text { Poland }\end{array}$ & $\begin{array}{c}\mathrm{M} \\
\text { Spain }\end{array}$ & $\mathrm{t}$ & $\mathrm{df}$ & $p$ & $\begin{array}{c}\mathrm{SD} \\
\text { Poland }\end{array}$ & $\begin{array}{c}\mathrm{SD} \\
\text { Spain }\end{array}$ & $\begin{array}{c}\text { Quotient } \\
\text { F of } \\
\text { variance }\end{array}$ & $\begin{array}{c}p \text { of } \\
\text { variance }\end{array}$ \\
\hline Rational & 35.76 & 32.71 & $4.956^{*}$ & $489.7^{*}$ & $<0.001^{*}$ & 5.60 & 8.12 & 2.10 & $<0.001$ \\
\hline Incorrect & 40.84 & 39.41 & 2.19 & 497 & 0.029 & 7.47 & 7.11 & 1.10 & 0.441 \\
\hline
\end{tabular}

* - $t$-test with independent group estimation; df - degree of freedom; M - arithmetic mean; SD - standard deviation; $p$ significance 
products not recommended for a healthy diet (cold-cuts, sausages and hotdogs). Insufficient consumption of fruit and vegetables may reduce the nutritional content and health values of diet, through a lower supply of dietary fibres (including lipid-soluble fractions) and mineral salts (including potassium and magnesium), and reducing the diet's antioxidant potential (an important factor in preventing, among others, cardiovascular and cancer diseases). Low consumption of wholegrain cereal products may reduce the supply of fibres (especially insoluble fractions) and B vitamins, catalysing, among others, metabolic processes [20]. In various studies, it has been confirmed that a diet rich in fresh fruit and vegetables, whole-grain cereals, legumes as well as sprouts and seeds, is an effective way to cover the body's antioxidant needs, including those for people with increased physical activity [11]. Low consumption of fermented dairy products may reduce the dietary intake of calcium (an early prevention factor for osteoporosis) and probiotic bacteria that enrich the intestinal microflora (and eubiosis state), with numerous pro-health values [4]. Relatively frequent (according to the median, several times a week) consumption of processed meat products (cold-cuts, sausages and hotdogs) may, in turn, increase the supply of saturated fatty acids and cholesterol, which in excess, have hyperlipidemic and hypertensive properties. The share of excess processed meat products in the etiology of cancer should also be emphasised [20].

In other research, nutritional mistakes among academic youth, including physical education students, both in Poland $[28,32,36]$ and in other countries, e.g. in Spain and Romania [6] and Chile [39], have also been confirmed. Errors in nutrition have also been described among students of other university faculties, including those Polish [14, 18, 24, 26, 38], Spanish [5, 17, 29, 42], Chinese [15], Brazilian [2] and American [41], Filipino [1], furthermore, from Zamora [31] and Bahrain [27]. Low vegetable consumption among students was also confirmed in a systematic review of works from 2009-2018 [34]. For example, the results of the author's research correspond to the tendencies described among 1st- and 2nd-year physical education students from Biała Podlaska, which showed a low level of both positive and unfavourable food choices, meaning that students did not choose products with a potentially beneficial effect for their health often enough, but at the same time, they restricted the consumption of unhealthy products, however, more beneficial choices were found among graduating students than those beginning their studies (more frequent consumption of fruit and vegetables vs. white bread, butter, cold-cuts and sweets) [32]. In another study conducted among students from the Warsaw University of Physical Education, the most common eating errors, in addition to too few meals and irregular consumption, were insufficient consumption of vegetables, fruit, wholemeal bread, milk and dairy products, and too frequent consumption of sweets, carbonated and alcoholic beverages as well as instant products and fast food [28], which also partly corresponds to the results of the author's research. Similarly, Chilean physical education students reported low consumption of vegetables and dairy products (men) and excessive consumption of sweet snacks (women) [39].

The discussed research conducted among Polish and Spanish physical education students also showed statistically significant differences in the frequency of consuming some product groups depending on the subjects' home country. Among Polish students, there was a tendency towards more frequent consumption of some products recommended in a healthy diet (fruit and vegetables, whole-grain cereal products, milk and fromage frais as well as poultry), but also more frequent consumption of some non-recommended products (purified cereal products, fatty, hard, blue and processes cheeses, butter, fried foods, sweets and confectionery as well as alcoholic beverages). At the same time, Spanish students significantly more often consumed the recommended legume seeds and sea fish, but also non-recommended products (red meat, fast food products as well as sweetened carbonated and non-carbonated beverages and energy drinks). Thus, nutrition errors were confirmed both among Polish and Spanish physical education students. It is impossible to clearly determine the direction and degree regarding the regularity of students' food choices depending on their country of origin, as Polish students were characterised by a significantly higher level of rational food choices, but at the same time, they consumed products with potentially adverse effects to health more often than students from Spain. Less rational nutritional behaviours of the Polish students may have reduced the supply of fibre while increasing the supply of saturated fatty acids. Spanish students could have also increased the risk of oversupply of saturated fatty acids, trans isomers and simple sugars that lower their health potential.

In another study, the aim of which was to compare Polish and Spanish (Gdańsk vs. Murcia) health behaviours of physical education students, the diversity of eating behaviours depending on home country was also confirmed. Students from the University of Murcia consumed seafood and dairy products more often, while sweetened carbonated and alcoholic beverages less often. In turn, students from Gdańsk consumed more vegetables. Regardless of the geographical factor, however, the authors of the study suggested the need to rationalise the diets (and other aspects of lifestyle) of students in a way that promotes 
early prevention of chronic diseases, including obesity and diabetes. At the same time, they suggested that the found differences may result from differences in culture, traditions and climatic factors (Northern vs. Southern Europe), but also from the implementation of an effective health policy since 2000 [25].

The results of research among Spanish medical students, which showed an excessive supply of saturated fatty acids (SFA) and a low supply of monounsaturated fatty acids (MUFA), also correspond to the relatively more frequent consumption of red meat, fast food products and vitamin D as well as E intake, suggesting deviations from the Mediterranean nutrition model [5]. Similarly, assessment of the diet of students from the University of Granada showed that eating habits, which deteriorate as the academic year progresses, are characterised by high consumption of protein products and fats, rich in saturated acids, with low consumption of products rich in dietary fibres [29]. There is also a corresponding tendency towards more frequent consumption of fruit and vegetables by Polish physical education students, which confirmed that the intake of flavonoid was more than twice as high among Polish than Spanish students ( 801 vs. $297 \mathrm{mg}$ /day). The most common sources of flavonoids were: vegetables, fruits (oranges), drinks (tea, orange juice) and spices (dried parsley, oregano). The demonstrated supply of flavonoids, in comparison to other population studies, was assessed as sufficient in both groups of students [23].

In other comparative studies on the geographical context concerning the implementation of the Mediterranean diet assumptions among physical education students from universities in Spain and Romania, it was shown that Spanish students followed the principles of the Mediterranean diet more than their Romanian peers [6]. Research in Catalonia also confirmed that students' eating habits deviate from the recommendations of the Mediterranean diet, because a high percentage of students followed a nutritional pattern characterised by low consumption of fruit (73.9\%), vegetables (39.8\%), wholemeal cereal products $(92.6 \%)$ and excessive consumption of red meat (84\%). These types of nutritional trends have been increasing in recent years in Spain and other industrialised countries [35]. A very small scale of implementing the recommendations of the Mediterranean diet in terms of limiting the consumption of fresh and processed meat (only 3.8\%) was also described in another group of students from eleven Spanish universities $(n=9,862)$ [30]. Nutritional blunders, particularly related to insufficient consumption of dairy products as well as fruit and vegetables, were also confirmed in other studies undertaken among students of other university centres in Poland and abroad [38]. Also, other research on the determinants of the nutritional behaviour of students from four European countries (Germany, Denmark, Poland and Bulgaria) has shown that food consumption patterns vary from country to country. Bulgarian students were distinguished by frequent consumption of sweets, cakes and fast food products, and Polish students by low consumption of vegetables and fruit [9].

The discussed research among Polish and Spanish physical education students also indicated statistically significant differences in the frequency of consuming some product groups depending on gender, with an indication of the tendency for less rational food choices of male students than female students, especially with regard to the consumption of high-milled cereal products, cold-cuts, sausages and hotdogs, red and canned meat, hard, blue and processed cheeses, fried foods, lard, sweetened carbonated beverages and energy drinks. Different trends concerned the more frequent consumption of sweets and confectionery products, and the less frequent consumption of legume seeds and fish by women. Less rational dietary behaviours among males, physical education students, increased the risk of a lower supply of fibres and a higher supply of saturated fatty acids. Less rational nutritional behaviours among women, students of physical education, may have increased the supply of simple sugars, while reducing the supply of polyunsaturated acids (PUFA) omega-3.

The demonstrated tendency towards more rational dietary choices among women than men is confirmed by the results of research among students of seven universities in Chile [8]. Also, research conducted among students of the Medical University of Wrockaw demonstrated numerous nutritional mistakes according to gender, with a higher percentage of men eating less than the recommended 3 meals a day, less frequently consuming 5 portions of fruit and vegetables daily or choosing low-fat dairy products not as often as they should, while including products with high GI and meat dishes more frequently than women. In addition, they used large amounts of salt or sugar to sweeten drinks more often [18]. In another study, variation in eating behaviours has also been shown depending on gender, including the greater incidence of fruit and vegetable consumption among women [10]. More rational dietary choices among women than men were also described in other population groups, including athletes (more frequent consumption of raw vegetables and dairy products with reduced fat content) [12]. Also, other research on the conditioning nutritional behaviours of students from four European countries (Germany, Denmark, Poland and Bulgaria) showed diversity of eating habits according to sex, while in all countries except for Bulgaria, men declared significantly more frequent consumption of snacks than women [9]. 
In the research, it is generally confirmed that students constitute a population group exposed to making nutritional mistakes, and their diet largely depends on living conditions/factors, in particular, income, knowledge about nutrition, education, housing conditions and professional work [37]. In the author's research, the predictive significance of the geographical context (country of origin) was also highlighted and the gender-specific diversity was confirmed. The nutritional profile of students indicates the need for nutritional education and the promotion of a healthy nutritional model in order to prevent the development of chronic diseases at later stages of ontogenesis, including obesity, cardiovascular as well as other diseases, which are also emphasized by other authors [7]. Nutritional education of physical education students is also important within the context of their future professional work, because as physical education teachers, they will be included in the implementation of school health education, the effectiveness of which may depend, among others, on the intensification of their individual pro-health attitudes, also towards rational nutrition [3].

\section{CONCLUSIONS}

Nutritional mistakes have been demonstrated among Polish and Spanish physical education students, particularly due to insufficient consumption of products with potentially beneficial effects on health (fruit, vegetables, whole-grain cereals, fermented milk products), as well as relatively frequent consumption of non-recommended meat products.

Among the Polish and Spanish students, there was significant differentiation in the frequency of consuming selected product groups according to country of origin, with Polish students consuming the recommended products more often (fruit and vegetables, whole-grains, milk, fromage frais and poultry), but at the same time, non-recommended products as well (purified cereals, fatty cheeses, butter, fried products, sweets and confectionery products as well as alcoholic beverages).

Among the Polish and Spanish physical education students, significant differentiation in the frequency of consuming selected product groups depending on gender was noted, with an indication of less rational dietary choices among men than women, associated with more frequent consumption of: purified cereal products, red meat, processed meat, fatty cheeses, fried foods, lard, and sweetened as well as energy drinks.

\section{Conflict of interest}

The authors declare no conflict of interest.

\section{REFERENCES}

1. Acampado E., Valenzuela M.: Physical activity and dietary habits of Filipino College students: CrossSectional Study. Kinesiology 2018;50(1):57-67. https:// doi.org/10.26582/k.50.1.11.

2. Alvarenga Mdos S., Lourenço B.H., Philippi S.T., Scagliusi F.B.: Disordered eating among Brazilian female college students. Cad Saude Publica 2013;29(5):879-888. https://doi.org/10.1590/S0102311X2013000500006

3. Chang L.C., Liao L.L., Chen M.I., Niu Y.Z., Hsieh P.L.: Strengthening teachers' abilities to implement a vision health program in Taiwanese schools. Health Educ Res 2017; 32(5): 437-447. http://doi.org/10.1093/her/cyx057.

4. Clark A., Mach N.: Exercise-induced stress behavior, gut-microbiota-brain axis and diet: a systematic review for athletes. J Int Soc Sports Nutr 2016; 13: 43. DOI: 10.1186/s12970-016-0155-6.

5. Correa-Rodríguez M., Pocovi G., Schmidt-RioValle J., González-Jiménez E., Rueda-Medina B.: Assessment of dietary intake in Spanish university students of health sciences. Endocrinol Diabetes Nutr 2018; 65(5): 265273. doi: 10.1016/j.endinu.2018.01.005.

6. Chacón-Cuberos R., Badicu G., Zurita-Ortega F., Castro-Sánchez M.: Mediterranean Diet and Motivation in Sport: A Comparative Study Between University Students from Spain and Romania. Nutrients 2018; 11(1): 30. doi: 10.3390/nu11010030.

7. De Piero A., Bassett N., Rossi A., Sammán N.: Trends in food consumption of university students. Nutr Hosp 2015; 31(4): 1824-1831. doi: 10.3305/nh.2015.31.4.8361.

8. Durán S., Crovetto M., Espinoza V., Mena F., Oñate G., Fernández M., Coñuecar S., Guerra A., Valladares M.: Lifestyles, body mass index and sleep patterns among university students. Rev Méd Chile 2017; 145(11). http:// dx.doi.org/10.4067/s0034-98872017001101403.

9. El Ansari W., Stock C., Mikolajczyk R.T.: Relationships Between Food Consumption and Living Arrangements Among University Students in Four European Countries - A Cross-Sectional Study. Nutr J 2012; 11(28). https:// doi.org/10.1186/1475-2891-11-28.

10. Emanuel A.S., McCully S.N., Gallagher K.M., Updegraff J.A.: Theory of Planned Behavior explains gender difference in fruit and vegetable consumption. Appetite 2012; 59(3): 693-697. doi: 10.1016/j.appet.2012.08.007.

11. Fraczek B., Morawska M., Gacek M., Pogoń K.: Antioxidant activity as well vitamin $\mathrm{C}$ and polyphenol content in the diet for athletes. Italian J Food Sci 2019;31(4):617-630. doi. http://dx.doi.org/10.14674/IJFS1510 .

12. Gacek M.: Selected personal conditions determining the frequency of consuming groups of products among athletes professionally training individual sport disciplines. Hum Mov 2019; 20(3): 56-65. doi: https:// doi.org/10.5114/hm.2019.83997.

13. Gawęcki J. (red.): Kwestionariusz do badania poglądów i zwyczajów żywieniowych oraz procedura opracowania danych. [Dietary Habits and Nutrition Beliefs Questionnarie and the Manual for Developing 
of Nutritional Data]. Wyd. Komitetu Nauki o Żywieniu Człowieka Polskiej Akademii Nauk, Warszawa 2014: 3-20. Available at: http://www.knozc.pan.pl/

14. Grygiel-Górniak B., Tomczak A., Krulikowska N., Przysławski J., Seraszek-Jaros A., Kaczmarek E.: Physical activity, nutritional status, and dietary habits of students of a medical university. Sport Sci Health J 2016;12(2):261-267. doi: 10.1007/s11332-016-0285-x.

15. Hu P., Huang W., Bai R., Zhang F., Sharma M., Shi Z., Xiao X., Abdullah A.S., Zhao Y.: Knowledge, Attitude, and Behaviors Related to Eating Out among University Students in China. Int J Environ Res Public Health 2016; 13(7): 696. doi: 10.3390/ijerph13070696.

16. http://www.fao.org/nutrition/education/food-dietaryguidelines/regions/europe/en/

17. Iglesias López M.T., Cuesta Santa Teresa E., Sáez Crespo A.: Comparative study of habits in students before and during the university in northwest area of Madrid. Nutr Hosp 2014; 31(2): 966-974. doi: 10.3305/ nh.2015.31.2.7703.

18. Ilow R., Regulska-Ilow B., Różańska D.: Dietary habits of Wroclaw Medical University students (Poland). Rocz Panstw Zakl Hig 2017;68(1):23-32.

19.Jakubiec D., Kornafel D., Cygan A., Górska-Kłęk L., Chromik K.: Lifestyle of Students From Different Universities in Wroclaw Poland. Rocz Panstw Zakl Hig 2015;66(4):337-344.

20.Kłosiewicz-Latoszek L.: Zalecenia żywieniowe w prewencji chorób przewlekłych [Dietary guidelines in prevention of chronic diseases]. Probl Hig Epidemiol 2009; 90(4): 447-450. (Polish)

21. Kosiba G., Gacek M., Wojtowicz A., Majer M.: Level of knowledge regarding health as well as health education and pro-health behaviours among students of physical education nad other teaching specialisation. Balt $\mathrm{J}$ Health Phys Act 2019; 11(1): 83-95. doi: 10.29359/ BJHPA.11.1.0.

22.Kosiba G., Gacek M., Wojtowicz A.: Preparation of teachers and students for the implementation of health education at school: survey review. Prz Bad Edukacyjnych 2020; 30(1): 161-175. DOI: http://dx.doi. org/10.12775/PBE.2020.009.

23.Kozłowska A., Przekop D., Szostak-Wegierek D.: Flavonoids intake among Polish and Spanish students. Rocz Panstw Zakl Hig 2015;66(4):319-325.

24.Likus W., Milka D., Bajor G., Jachacz-Lopata M., Dorzak B.: Dietary habits and physical activity in students from the Medical University of Silesia in Poland. Rocz Panstw Zakl Hig 2013;64(4):317-324.

25.Lopez-Sanchez G.F., Radzimirski L., Skalska M., Jastrzębska J., Smith L., Wakuluk D., Jastrzębski Z.: Body composition, physical fitness, physical activity and nutrition in Polish i Spanish male students of sports sciences: differences and correlations. Int $\mathrm{J}$ Environ Res Public Health 2019;16(7):1148. doi: 10.3390/ ijerph16071148.

26. Mędrela-Kuder E.: Ocena stylu życia studentów fizjoterapii i edukacji techniczno-informatycznej na podstawie żywienia i aktywności fizycznej. [Evaluation of the life style of physiotherapy and technical-computer science students as a case study pertaining to diet and physical activity]. Rocz Panstw Zakl Hig 2011;62(3):315318. (Polish)

27. Musaiger A.O., Awadhalla M.S., Al-Mannai M., AlSawad M., Asokan G.V.: Dietary Habits and Sedentary Behaviors Among Health Science University Students in Bahrain. Int J Adolesc Med Health 2017; 29(2). DOI: 10.1515/ijamh-2015-0038.

28. Myszkowska-Ryciak J., Kraśniewska A., Harton A., Gajewska D.: Porównanie wybranych zachowań żywieniowych studentek Akademii Wychowania Fizycznego i Szkoły Głównej Gospodarstwa Wiejskiego. [Comparison of selected nutritional behaviors of female students of the University of Physical Education and of the University of Life Sciences in Warsaw]. Probl Hig Epidemiol 2011;92(4):931-934. (Polish)

29. Navarro-Prado S., González-Jiménez E., MonteroAlonso M.A., López-Bueno M., Schmidt-RioValle J.: Life style and monitoring of the dietary intake of students at the Melilla campus of the University of Granada. Nutr Hosp 2015;31(6):2651-2659. doi: 10.3305/ nh.2015.31.6.8973.

30. Ortiz-Moncada R., Morales-Suárez-Varela M., AvecillaBenítez A., Norte Navarro A., Olmedo-Requena R., Amezcua-Prieto C., Cancela J.M., Blázquez Abellán G., Mateos-Campos R., Valero Juan L.F., Redondo Martín S., Alonso-Molero J., Molina de la Torre A.J., LlopisMorales A., Peraita-Costa I., Fernández-Villa T: Factors Associated with Meat Consumption in Students of Spanish Universities: UniHcos Project. Int J Environ Res Public Health 2019; 6(20): 3924. doi: 10.3390/ ijerph16203924.

31. Pastor R., Bibiloni M.D.M., Tur Marí J.A.: Food consumption patterns among university students in Zamora. Nutr Hosp 2017; 34(5):1424-1431. doi: 10.20960/nh.1147.

32.Popławska H., Dmitruk A., Kunicka I., Dębowska $A$., Holub W.: Habits and knowledge about food and nutrition among physical education students depending on their level of higher education and physical activity. Pol J Sport Tourism 2018:25:35-41. DOI: https://oi. org/10.2478/pjst-2018-0018.

33. Remick A.K., Polivy J., Pliner P.: Internal and external moderators of the effect of variety on food intake. Psychol Bull 2009; 135(3): 434-451. doi: 10.1037/a0015327.

34.Rodrigues V.M., Bray J., Fernandes A.C., Bernardo G.L., Hartwell H., Martinelli S.S., Uggioni P.L., Cavalli S.B., Proenca R.P.D.: Vegetable Consumption and Factors Associated with Increased Intake among College Students: A Scoping Review of the Last 10 Years. Nutrients 2019; 11(7): DOI: 10.3390/nu11071634.

35. Sánchez Socarrás V., Aguilar Martínez A.: Food habits and health-related behaviors in a university population. Nutr Hosp 2014; 31(1): 449-457. doi: 10.3305/ nh.2015.31.1.7412.

36.Skrzypek A., Szeliga M., Stalmach-Przygoda A., Kowalska B., Jabłoński K., Nowakowski M.: Analysis of Lifestyle and Risk Factors of Atherosclerosis in Students of Selected Universities in Krakow. Przegl Lek 2016; 73(5): 316-319. 
37. Stefańska E., Ostrowska L., Radziejewska I., Kardasz M.: Sposób żywienia studentów Uniwersytetu Medycznego w Białymstoku w zależności od miejsca zamieszkania $\mathrm{w}$ trakcie studiów [Mode on nutrition in students of the Medical University of Bialystok according to their place of residence during the study period]. Probl Hig Epidemiol 2010;91(4):585-590. (Polish)

38.Szczuko M., Gutowska I., Seidler T.: Nutrition and nourishment status of Polish students in comparison with students from other countries. Rocz Panstw Zakl Hig 2015;66(3):261-268.

39. Valdes-Badilla P., Godoy-Cumillaf A., HerreraValenzuela T., Durán-Agüero S.: The comparison between food habits and physical condition among physical education and other undergraduate students. Nutr Hosp 2015;32(2):829-836. doi: 10.3305/ nh.2015.32.2.9194.

40.Yager Z., Gray T., Curry C., McLean S.A.: Body dissatisfaction, excessive exercise, and weight change strategies used by first-year undergraduate students: comparing health and physical education and other education students. Int J Eat Disord 2017;5(10): doi: 10.1186/s40337-016-0133-z.

41. Yahia N., Wang D., Rapley M., Dey R.: Assessment of weight status, dietary habits and beliefs, physical activity, and nutritional knowledge among university students. Perspect Public Health 2016; 136(4): 231-244. doi: 10.1177/1757913915609945.

42.Zazpe I., Marqués M., Sánchez-Tainta A., RodríguezMourille A., Beunza J.J., Santiago S., FernándezMontero A.: Eating habits and attitudes towards change in Spanish university students and Wolkers. Nutr Hosp 2013; 28(5):1673-1680. doi: 10.3305/nh.2013.28.5.6553.

Received: 16.04 .2020

Accepted: 28.05 .2020 